\title{
MENURUNKAN PERILAKU SISWA TERLAMBAT MASUK SEKOLAH MELALUI KONSELING KELOMPOK DENGAN TEKNIK RESTRUKTURING KOGNITIF
}

\author{
Akhmad Baihaqi, S.Psi. \\ SMK Wali Songo 2 Gempol Pasuruan \\ mubah100@gmail.com \\ Riyanti Utami \\ SMA Negeri 1 Kalianget \\ riyantiutami22@gmail.com
}

\begin{abstract}
Abstrak
Tujuan dari studi kasus ini adalah untuk mengetahui; Model keterlambatan peserta didik, faktor penyebab keterlambatan peserta didik, penanganan tim tatib, guru BK, waka kesiswaan terhadap peserta didik yang datang terlambat, kendala dalam menangani peserta didik yang datang terlambat dan upaya konselor menangani hambatan tersebut, persepsi peserta didik terlambat yang telah mendapatkan penanganan dari konselor, dan hasil dari penanganan guru BK SMK Walisongo 2 Gempol terhadap peserta didik yang datang terlambat. Jenis penelitian ini adalah penelitian kualitatif yang menggunakan metode studi kasus. Dalam penelitian studi kasus ini teknik pengumpulan data yang digunakan yakni teknik wawancara dan dokumentasi. Analisis data yang digunakan yaitu triangulasi, baik triangulasi sumber maupun triangulasi teknik. Subjek penelitian yang akan digunakan dalam penelitian ini adalah peserta didik yang terlambat datang ke sekolah di SMK Walisongo 2 Gempol serta diambil 6 peserta didik yang terlambat 3 kali berturut-turut, wawancara oleh 2 Guru BK, dan waka kesiswaan. Hasil penelitian yang diperoleh terkait keterlambatan peserta didik SMK Walisongo 2 Gempol sejumlah 6 peserta didik, dari 6 peserta didik itu diberi penanganan menggunakan teori Gestalt restrukturing kognitif melalui konseling kelompok serta konseling individual dengan guru BK. Dari jangka waktu penelitian 1 bulan, 3 dari 6 peserta didik mengulangi keterlambatannya sampai 3 kali berturut-turut. Sehingga peserta didik yang mengulangi keterlambatannya tersebut diberi penanganan oleh konselor berupa konseling individual/konseling kelompok dan jika masih mengulanginya lagi hingga 3 kali, maka konselor akan memanggil orang tua siswa untuk datang ke sekolah.
\end{abstract}

Kata Kunci: Studi, Penanganan, Peserta Didik Terlambat

\begin{abstract}
The purpose of this case study is to find out the model of student delay, factors causing students' delay, handling of the team of directors, counseling teachers, student time for students who arrive late, constraints in dealing with students who arrive late and the counselor's efforts to deal with these obstacles, the perception of late students who have received treatment from the counselor, and the results of the handling of the BK SMK Walisongo 2 Gempol teacher for students who came late. This type of research is a qualitative research using the case study method. In this case study research, the data collection techniques used were interview and documentation techniques. The data analysis used was triangulation, both source triangulation and technical triangulation. Research subjects to be used in this study were students who came late to school at SMK Walisongo 2 Gempol and taken 6 students who were late 3 times in a row, interviewed by 2 counseling teachers, and student time. The results obtained related to the delay of students of SMK Walisongo 2 Gempol are 6 students, they were given treatment using cognitive restructuring theory through group counseling and individual counseling with counseling teachers. From the study period of a month, 3 out of 6 students repeated the delay up to 3 times in a row. So that students who repeat the delay are given treatment by the counselor in the form of individual counseling / group counseling and if they still repeat it up to 3 times, the counselor will call the parents of students to come to school.
\end{abstract}

Keywords: Study, Treatment, Students who are late 
Jurnal HELPER, Vol 37 No 1 (2020) 23 - 31

Bimbingan dan Konseling Universitas PGRI Adi Buana Surabaya

ISSN: 02162938

\section{LATAR BELAKANG}

Banyak sekali peraturan atau tata tertib yang ada di sekolah. Hal tersebut diperlukan sebagai dasar dan pedoman dalam mengatur sistem kinerja personil di sekolah. Tata tertib dibuat untuk dibuat dan dijalankan serta dipatuhi oleh semua pihak di sekolah, baik guru, staf, guru piket, tim tatib terutama peserta didik dan yang menjadi ujung tombak yakni kepala sekolah, jika tata tertib dilanggar, maka akan ada panismen atau sanksi yang akan diberikan.

Pelanggaran tata tertib yang tidak ditaati oleh peserta didik banyak diketahui di sekolah, pelanggaran merupakan tindakan yang melanggar aturan yang sudah dibuat dan disahkan. Hal ini akan menjadi salah satu penyebab terjadinya berbagai bentuk kenakalan yang dilakukan peserta didik, baik di dalam maupun di luar sekolah. Dari pernyataan Tarmizi tersebut dapat diketahui bahwa terdapat berbagai macam bentuk pelanggaran peserta didik di sekolah, misalnya membolos, terlambat masuk ke sekolah dan lain sebagainya.

Makna dari terlambat dalam KBBI adalah lewat dari waktu yang ditentukan. Maka terlambat datang ke sekolah berarti peserta didik datang ke sekolah lewat dari waktu yang ditentukan, misalnya peraturan sekolah menetapkan jam masuk sekolah adalah pukul 07.00 WIB, namun peserta didik datang pukul 07.05 maka dikatakan terlambat.

Ternyata masih terlihat fenomena peserta didik yang terlambat masuk sekolah di SMK Walisongo 2 Gempol. Tentunya dengan alasan dan faktor yang bervariasi yang melatar belangkangi perilaku kurang disiplin. Permasalahan ini juga terjadi di SMA Walisongo dalam satu yayasan di YLPM Ma'arif Walisongo.

Keterangan di atas kebiasaan datang terlambat ini timbul karena adanya kurang tanggung jawab pada dirinya sendiri, berdasarkan observasi dan wawancara guru BK SMK Walisongo 2 Gempol pada bulan Oktober 2020 pertama kali masuk tatap muka meskipun dengan sistem bergilir di saat pandemi covid-19 penyebab peserta didik datang terlambat terdapat beragam alasan yang dikemukakan oleh para peserta didik seperti: bangun kesiangan, tidak ada barengan ketika berangkat, sengaja datang terlambat dengan menunggu teman yang lain, masih nongkrong di parkiran sepeda motor di sekitar sekolah, dan jalannya macet. Apapun alasannya dan faktornya perilaku terlambat masuk sekolah tetaplah dikatakan sebagai seseorang yang tidak disiplin, tidak patuh dengan peraturan yang telah ditetapkan. Dalam hal ini peserta didik kurang tanggung jawab karena tidak dapat memperkirakan waktu untuk datang tepat waktu. Tetapi jika penyebab terlambat tersebut peserta didik datang ke sekolah mampu mengelola waktunya dengan baik dan benar, maka perilaku terlambat datang ke sekolah dapat dihindari.

Menurut Supriyanto (2013) pelanggaran yang dilakukan peserta didik dengan terlambat datang ke sekolah dapat menghambat proses pembelajaran. Peserta didik yang terlambat cenderung mengganggu teman-teman lain 
Jurnal HELPER, Vol 37 No 1 (2020) 23 - 31

Bimbingan dan Konseling Universitas PGRI Adi Buana Surabaya

ISSN: 02162938

yang sedang belajar, di sisi lain peserta didik yang terlambat datang ke sekolah dapat pula mempengaruhi teman-temannya untuk berbuat tidak baik, malas untuk belajar, serta menjadikan pembelajaran sekolah tidak kondusif bagi kegiatan pembelajaran. Peserta didik akan terlambat optimalisasi potensi dan prestasinya serta terhambat dalam mencapai kesuksesan masa depannya.

Dan pada kenyataannya yang terjadi bahwa sebagian peserta didik yang mengidentifikasikan adanya masalah perilaku terlambat datang ke sekolah dipengaruhi oleh faktor keluarga, faktor pribadi dan faktor sekolah yang berpengaruh pada prestasi belajar peserta didik di sekolah.

Supriyanto, 2013). Penyebab munculnya perilaku terlambat yang ditimbulkan dari faktor keluarga misalkan peserta didik belum berangkat ke sekolah disuruh untuk mengantar orang tua ke pasar dan lain sebagainya. Sedangkan munculnya perilaku terlambat yang disebabkan oleh faktor pribadi adalah peserta didik yang memiliki kebiasaan bangun tidur kesiangan karena pada malam harinya begadang sehingga terjadi keterlambatan masuk sekolah. Dan juga jarak antara rumah dan sekolah juga menjadi salah satu faktor penyebab keterlambatan peserta didik, ditunjang dengan sulitnya mendapatkan akses transportasi umum. Selain itu juga penyebab tersebut kebiasaan datang terlambat juga disebabkan adanya kebiasaan peserta didik yang mempunyai kebiasaan buruk seperti memang sengaja datang diterlambatkan, menunda berangkat ke sekolah, dan alasan yang biasa adalah menunggu teman. Akan tetapi jika peserta didik mampu mengelolah waktunya dengan baik, maka peserta didik tidak akan terlambat masuk sekolah.

Perilaku terlambat datang ke sekolah merupakan perilaku maladaptif yang sering dijumpai di seluruh instansi pendidikan (Retnoningtyas, 2015). Permasalahan terlambat datang ke sekolah telah ditemui di SMK Walisongo 2 Gempol. Dari hasil observasi yang dilakukan dengan mengambil data dari buku catatan pelanggaran tata tertib sekolah, dalam kurun satu minggu terdapat siswa yang terlambat dengan frekuensi keterlambatan rata-rata 10-15 peserta didik (1$2 \%)$. Bermacam-macam alasan seperti ban bocor, menunggu teman, tidak ada sepedahnya, macet dan lain sebagainya.

Dengan menunjukann perilaku terlambat tentunya sangat memberikan dampak negatif bagi peserta didik dan lingkungan sekitar terutama di kelas jurusan lain. Peserta didik yang melanggar tata tertib salah satunya terlambat akan diberikan panismen yang sudah sepakati oleh tim tatib dan kesiswaan, selain itu mereka jelas ketinggalan pelajaran di jam pertama dimana itu akan berdampak terhadap penilaian peserta didik tersebut. Sedangkan dampak bagi lingkungan sekitar yakni menganggu jalannya proses belajar mengajar yang sedang berlangsung di dalam kelas. Peserta didik yang datang terlambat akan menjadi pusat perhatian terutama pada waka kesiswaan karena mereka masuk disaat peserta didik yang lain sedang melaksanakan pembelajaran bersama bapak ibu guru. Peserta didik yang demikian itu dapat dikatakan sikap atau perilaku kurang baik, sehingga perlu 
Jurnal HELPER, Vol 37 No 1 (2020) 23 - 31

Bimbingan dan Konseling Universitas PGRI Adi Buana Surabaya

ISSN: 02162938

untuk ditangani agar perilaku tersebut tidak terulangi lagi.

Di SMK Walisongo 2 Gempol memiliki cara dalam mendisplinkan peserta didik yang terlambat, peserta didik yang datang terlambat 1x mendapat bimbingan atau peringatan dan itu ada catatannya setiap kali peserta didik melakukan terlambat, jika dikemudian hari peserta didik itu terlambat lagi dengan nama yang sama, maka peserta didik tersebut akan diberikan surat yang isinya berupa komitmen bahwa peserta didik tersebut tidak akan mengulangi lagi, jika mengulangi lagi sampai $3 x$ maka peserta didik tersebut dipanggil orang tuanya.

Pada awal masuk setelah libur sesuai surat edaran dari bupati Pasuruan SMK Walisongo sudah mulai masuk meskipun hanya 2 jam pelajaran tatap muka dengan membiasakan siswa siswinya untuk hidup disiplin. Kami tim Tatib mempunyai aturan yang cukup ketat terhadap jam masuk. Pada gelombang I pukul 06.50, gelombang II pukul 09.50, gelombang III pukul 12.50, dan gelombang IV pukul 14.50 gerbang sekolah sudah ditutup. Tidak ada sedikitpun toleransi bagi mereka yang sudah terlambat memasuki gerbang sekolah. Namun sayangnya, berdasarkan observasi awal yang dilaksanakan pada saat awal pertama masuk tanggal 12 Oktober 2020 ada 9 peserta didik yang terlambat, lalu pada tanggal 13 Oktober ada 8 peserta didik yang terlambat. Pada tanggal 14 Oktober ada 15 peserta didik yang terlambat. dari total siswa kelas $\mathrm{X}$ sebanyak 583 siswa. Mereka datang dengan berbagai alasan keterlambatan, seperti ban bocor, bangun kesiangan dan lainnya.
Terlambat datang ke sekolah merupakan sesuatu yang cukup fatal akibatnya. Siswa tidak bisa mengikuti pelajaran selama beberapa menit atau bahkan beberapa jam pelajaran. Hal ini akan mengganggu jalannya proses pembelajaran bagi siswa lain, karena siswa yang baru datang mengambil perhatian siswa lain yang sudah fokus terhadap pelajaran yang diberikan.

Menurut Cormier \& Nurius (dalam Krisnayana dkk, 2014: 6) bahwa restrukturisasi kognitif berakar pada pengapusan distorsi kognitif atau kesimpulan yang salah, pikiran, keyakinan irasional, dan mengembangkan kognisi baru dengan pola respon yang lebih baik atau sehat. Konseling kelompok sebagai salah satu bentuk konseling dipandang memiliki kelebihankelebihan dibandingkan dengan konseling individual. Kelebihan konseling kelompok tersebut antara lain adalah kemampuannya dalam membantu menangani suatu permasalahan yang timbul dengan lebih efisien tanpa mengesampingkan efektifitasnya. Sisi efisiennya adalah kemampuan konseling kelompok dalam menghemat waktu dan tenaga konselor dalam membantu dan menangani permasalahan peserta didik yang banyak timbul di sekolah.

\section{METODOLOGI}

Metode yang digunakan dalam penelitian ini adalah metode adalah studi kasus. Studi kasus merupakan suatu metode untuk menyelidiki atau mempelajari suatu kejdian mengenai perseorangan (riwayat hidup). Pada metode studi kasus ini diperlukan informasi guna mendapatkan info yang lebih banyak. W.S 
Jurnal HELPER, Vol 37 No 1 (2020) 23 - 31

Bimbingan dan Konseling Universitas PGRI Adi Buana Surabaya ISSN: 02162938

Winkel dan Sri Hastuti (2006) menyatakan bahwa studi kasus dalam rangka pelayanan bimbingan merupakan metode untuk mempelajari keadaan dan perkembangan peserta didik secara lengkap dan mendalam, dengan tujuan memahami individualitas peserta didik dengan baik dan membantunya dalam perkembangan selanjutnya. Alasan mengapa menggunakan studi kasus, karena:

a. Penelitian studi kasus berupaya mencari kebenaran ilmiah dengan cara memusatkan perhatian pada suatu kasus secara intensif dan mendetail.

b. Penelitian studi kasus mengkaji secara mendalam tentang peristiwa, lingkungan, dan situasi tertentu yang memungkinkan mengungkapkan atau memahami sesuatu. Sesuai dengan alasan di atas penelitian ini ingin mengkaji secara mendalam tentang peristiwa atau situasi dalam rangka berupaya mencari kebenaran ilmiah dengan cara mempelajarinya secara intensif dan mendetail. 
Jurnal HELPER, Vol 37 No 1 (2020) 23 - 31

Bimbingan dan Konseling Universitas PGRI Adi Buana Surabaya

ISSN: 02162938

\section{HASIL PENELITIAN}

a. Model keterlambatan peserta didik dari pemaparan informan yaitu guru tatib dan guru piket dan dua orang guru BK, sama dengan yang telah dipaparkan oleh 9 peserta didik, paling banyak terjadi keterlambatan di hari pertama masuk tanggal 12 Oktober. Di hari itu para peserta didik beranggapan bahwa itu adalah hari yang belum ketat karena baru pertama kali masuk. Tapi justru membuat mereka terlambat mungkin anggapan mereka ada apel karena baru pertama kali masuk.

b. Penanganan tim tatib dan guru piket terhadap peserta didik yang terlambat pintu gerbang ditutup pukul 07.05 tepat. peserta didik yang terlambat harus menunggu di depan pintu gerbang terlebih dahulu hingga peserta didik yang lain telah memasuki dan mengikuti apel. Ketika doa bersama peserta didik terlambat diperbolehkan masuk dan berkumpul di depan pos satpam. Masing- masing dari mereka ditanyai satu persatu dan diberi bimbingan terkait kedisiplinan kemudian peserta didik mengisi buku catatan keterlambatan bagian dari tim ketertiban sekolah. Dari hasil penanganan itu nanti dapat dipertanggungjawabkan oleh pihak ketertiban sekolah dan bekerja sama tim tatib dengan guru BK. Setelah selesai di catat peserta didik disarankan ke ruang BK untuk diberi layanan bimbingan dan konseling sepenuhnya peserta didik terlambat adalah tanggung jawab guru BK.

c. Anggapan dari peserta didik terlambat dari penanganan yang diberikan oleh tim tatib, guru piket dan guru BK terhadap peserta didik yang terlambat sudah memberikan panismen. Namun kembali lagi pada diri masing-masing peserta didik, apakah dengan merasa jera itu mereka merubah perilaku maladaptif, atau justru belum menemukan solusinya dan mengulangi keterlambatannya lagi.

d. Dari hasil penanganan konselor setelah mendapat layanan dari pihak sekolah, hasil dapat dilihat secara jelas, bahwa 5 dari 9 orang yang terlambat pada tanggal 13 April 2020, tidak terlambat lagi setelah tanggal tersebut sampai penelitian ini selesai dilakukan.

\section{PEMBAHASAN}

Pada pembahasan ini dijelaskan bahwa kasus, peneliti yang kemudian dikaitkan dengan teori bimbingan konseling serta teori yang digunakan dalam membimbing peserta didik yang terlambat yaitu dengan konseling kelompok menggunakan teknik restrukturing kognitif serta sumbangan ilmu atau kebijakan. Model perilaku terlambat peserta didik di SMK Walisongo 2 Gempol, banyak peserta didik yang terlambat pada gelombang 3 dan 4 , mungkin dirasa longgar karena dari tim tatib sebagian ada tugas lain menurut mereka. Namun dalam penelitian ini, memang jelas masuk gelombang 3 dan 4 yang paling sering terjadi pelanggarannya. Pada gelombang 3 dan 4 peserta didik merasa lebih santai dibanding dengan gelombang 1 dan 2. Dengan hasil rekapan nampaknya gelombang 3 dan 4 yang paling sering muncul peserta didik terlambat, pihak sekolah dapat lebih menekankan peraturan lagi pada gemlombang ke 3 dan 4 
Jurnal HELPER, Vol 37 No 1 (2020) 23 - 31

Bimbingan dan Konseling Universitas PGRI Adi Buana Surabaya

ISSN: 02162938

agar peserta didik tidak menyepelekan.

Faktor yang menjadi penyebab keterlambatan peserta didik SMK WAlisongo 2 Gempol ada 2, yaitu faktor internal dan faktor eksternal. Faktor internal yaitu faktor yang berasal dari diri sendiri. Sedangkan faktor eksternal adalah faktor yang berasal dari luar. Seperti yang terjadi pada banyak subjek penelitian, sebagian besar dari mereka terlambat karena kesalahan dari diri sendiri. Beberapa bangun kesiangan karena pada malam harinya mereka tidak segera tidur. Yang paling parah adalah peserta didik sudah berangkat dari rumah lebih awal namun masih nongkrong di parkiran sepeda motor sambil nunggu temannya yang belum datang.

Selanjutnya faktor yang berasal dari diri sendiri itu dapat dirubah apabila ada kesadaran dari diri sendiri bahwa kedisplinan turut menunjang keberhasilan peserta didik dalam pendidikan. Atau dengan dukungan dari luar, misalnya dengan adanya kemajuan teknologi bisa dibentuk WhatsApp, untuk dibentuk group. Di dalam grup tersebut dibentuk ketua kelas atau lebih maksimal dari bpk/ibu wali kelas berkoordinasi dengan wali murid sebagai bentuk tanggung jawabnya. Setiap pagi, wali kelas ditambah beban tugas untuk mengecek seluruh anak didiknya sudah bersiap ke sekolah atau belum. Sedangkan faktor eksternal yang terjadi pada seorang peserta didik yang membuatnya terlambat masuk di sekolah hingga berkali kali. Ketika orang tuanya sibuk atau ada pekerjaan yang berangkat pagi sebelum anaknya berangkat ke sekolah sehingga menyuruh peserta didik ini untuk mengantarkan adiknya yang masih duduk di sekolah dasar atau SMP. Ketika orang tua diundang ke sekolah, mereka mengaku bahwa hal tersebut telah diketahui dan memang mengijinkan anaknya untuk terlambat. Guru BK selalu mencari upaya agar bisa meminimalisir keterlambatan pada peserta didik. Seperti yang telah dilakukan sekarang. Mereka bekerja sama dengan bagian ketertiban sekolah dalam menangani siswa yang terlambat.

Penenerapan teori Gestalt behavioristik restrukturing kognitif melalui konseling kelompok dengan memberikan layanan mengubah pikiran negatif menjadi positif peserta didik yang terlambat yaitu dengan membuat surat pernyataan komitmen.

Setelah peserta didik mendapat penanganan sesuai dengan peraturan yang berlaku oleh pihak ketertiban sekolah yaitu membuat surat pernyataan komitmen peserta didik yang terlambat diarahkan ke ruang BK untuk melaksanakan konseling kelompok dengan teknik restrukturing kognitif. Guru BK sangat menjaga asas dalam pemberian konseling kelompok ini. yang terdiri dari asas kerahasiaan, asas kesukarelaan, asas keterbukaan, dan asas kenormatifan. Guru BK harus bisa menggali dengan baik penyebab keterlambatan peserta didik bisa berasal dari dirinya sendiri atau dari orang lain. Setiap permasalahan pasti ada solusinya. Begitupun dengan keterlambatan para peserta didik ini seharusnya dapat ditemukan solusinya.

Ketika peserta didik yang harus mendatangkan orang tuanya ke sekolah karena telah terlambat lebih dari tiga kali, konselor harus bisa menjadi penengah permasalahan antara peserta didik 
Jurnal HELPER, Vol 37 No 1 (2020) 23 - 31

Bimbingan dan Konseling Universitas PGRI Adi Buana Surabaya ISSN: 02162938

dengan orang tuanya. Hal ini dilakukan untuk menjaga kerjasama antara sekolah dan orang tua peserta didik demi tercapainya keberhasilan dan tujuan bersama. Dengan teknik restrukturing kognitif yang diberikan pihak sekolah, diharapkan ada perubahan perilaku yang berasal dari kesadaran diri siswa itu sendiri.

Syukur Alhamdulillah sangat tampak hasilnya terhadap penurunan keterlambatan peserta didik di SMK Walisongo 2 Gempol setelah diberi layanan atau penanganan. Namun masih ada peserta didik yang terlambat hanya berkisar 3 sampai 5 peserta didik dalam tiap gelombang itu sudah wajar.

Tentunya hal ini merupakan kerja sama tim tatib dan pihak terkait, dengan berkurangnya jumlah peserta didik yang terlambat, proses kegiatan belajar mengajar berlangsung lancar tanpa ada gangguan dari peserta didik yang terlambat masuk ke ruang kelasnya masingmasing. Dengan usaha penerapan secara restrukturing kognitif yang digunakan untuk menangani peserta didik yang terlambat, tentunya pihak sekolah bersedia membagi ilmunya khususnya kepada unit lain karena sekolah kami dalam satu yayasan namun ada beberapa unit mulai TK sampai dengan Perguruan tinggi.

\section{KESIMPULAN}

Kesimpulan ini akan diuraikan dari proses studi kasus yang telah dilakukan.

1. Keterlambatan peserta didik SMK Walisongo 2 Gempol membentuk model sebagai berikut:

a. Peserta didik yang masuk gelombang 3 berdasarkan data paling sering terjadi keterlambatan

b. Keterlambatan peserta didik dimenit sejak 1-10 menit, bahkan ada yang sampai 20 menit setelah bel dibunyikan.

c. Sebagian besar banyak peserta didik yang terlambat yang masih nongkrong di parkiran sepeda motor yang berada di sekitar sekolah.

2. Faktor yang melatar belakangi keterlambatan peserta didik masuk di sekolah ada dua, yaitu faktor internal dan faktor eksternal. Hasil studi kasus menyimpulkan bahwa faktor yang paling sering menyebabkan peserta didik terlambat masuk di sekolah adalah faktor internal atau faktor yang berasal dari dirinya sendiri. Seperti terlambat bangun kesiangan.

3. Guru BK memberikan layanan konseling kelompok dengan teknik restrukturing kognitif yang tujuannya merubah tingkah laku peserta didik terlambat dengan adanya fikiran yang negatif di rubah menjadi pikiran yang positif.

\section{SARAN}

Berdasarkan pembahasan dan kesimpulan tersebut, maka saran yang berkaitan dengan hasil studi kasus, yakni studi kasus tersebut menunjukkan bahwa konseling kelompok restrukturing kogntif dapat mengurangi perilaku terlambat peserta didik masuk sekolah, maka guru BK dapat menggunakan konseling kelompok restrukturing kognitif sebagai salah satu alternatif bantuan yang dapat digunakan untuk membantu mengurangi perilaku 
Jurnal HELPER, Vol 37 No 1 (2020) 23 - 31

Bimbingan dan Konseling Universitas PGRI Adi Buana Surabaya ISSN: 02162938

terlambat.

\section{DAFTAR PUSTAKA}

Supriyanto, Agus. 2013. Mengatasi Perilaku Terlambat datang ke sekolah Melalui Konseling Individual Pendekatan Behavioristik Dengan Teknik BehaviorShaping di SMP Negeri 19 Semarang Tahun Ajaran 2011/2012. online (http://lib.unnes.ac.id/12088, diakses 25 Januari 2020).

Alamri,N. (2015). Layanan Bimbingan Kelompok Dengan Teknik Self Management Untuk Mengurangi Perilaku Terlambat Masuk Sekolah(Studi Pada Siswa Kelas X SMA 1 Gebog Tahun 2014/2015). Jurnal Konseling Gusjigang, 1(1). https://doi.org/10.24176/jkg.v1i1.259.

Retnoningtyas, Lindah. 2015. Penerapan Teknik Behavoir Contract untuk Mengurangi Perilaku Terlambat Masuk Sekolah Pada Siswa SMP Negeri 2 Gedangan. Skripsi Tidak diterbitkan.
Surabaya : UNESA.

W. S. Winkel \& M.M. Sri Hastuti. 2006. Bimbingan Dan Konseling Di Institusi Pendidikan. Yogyakarta: Media Abadi.

Moleong, L. J. (2016). Metodologi Penelitian Kualitatif. Bandung: Remaja Rosdakarya.

Aminah, 2011, Mendisiplinkan Anak di Sekolah, Bandung: Tarsito. Arikunto, Suharsimi. 2010, Prosedur Penelitian: Suatu Pendekatan Praktik, Jakarta: Rineka Cipta. Chatarina, Tri Anni. 2013.

KrisnayanaT.A. I N, Dkk. (2014). Penerapan Konseling Kognitif dengan Teknik Restrukturisasi Kognitif untuk Meningkatkan Resiliensi Siswa Kelas XI IPA 1 SMA NEGERI 3 SINGARAJA. Jurnal Bimbingan dan Konseling. Universitas Pendidikan Ganesha. Singaraja. Vol 2 No 1. (Diakses tanggal 27 Januari 2020). 